\title{
Influence of Culture Substrates and Biostimulators on Passiflora Rooting
}

\author{
Paula BOBOC (OROS), Corina CATANA, Tincuta GOCAN, Gelu MOLDOVAN, Zsolt SZÉKELY-VARGA and \\ Maria CANTOR*
}

Faculty of Horticulture, University of Agricultural Sciences and Veterinary Medicine, Cluj-Napoca, Romania, 3-5 Mănăştur St, 400372, Cluj-Napoca

*corresponding author: marcantor@yahoo.com

BulletinUASVM Horticulture 77(1) / 2020

Print ISSN 1843-5254, Electronic ISSN 1843-5394

DOI:10.15835/buasvmcn-hort: 2019.0013

\begin{abstract}
Passiflora quadrangularis and Passiflora caerulea commonly known as passion flower are two voluble species appreciated for their impressive flowers and delicious fruits. The aim of the presented experiment was to compare the effect of different rooting substrates (vermiculite, peat+vermiculite, peat+pearlite, peat+sand) and biostimulators (Radistim-2; Incit-8, IBA 1000 ppm and control - untreated cuttings) on the rooting of stem cuttings from $P$. caerulea and P. quadrangularis. Stem cuttings of approximately $15 \mathrm{~cm}$ length were harvested from the medial portions of the shoots from mature plants. Regarding the rooting rate by species, it has been found that P.caerulea obtained a $79.78 \%$ cuttings rooting average compared to $P$. quadrangularis which had a rooting average of $74.57 \%$. Vermiculite and the treatment with IBA $1000 \mathrm{ppm}$ highly influence the length and number of roots. Establishing the most suitable measures for vegetative propagation by cuttings of Passiflora species studied could lead to the expansion of their culture in our country.
\end{abstract}

Keywords: cuttings, Passiflora caerulea, Passiflora quadrangularis, vegetative propagation

\section{Introduction}

Recently, the import of ornamental flowering plants had been increasing, with the need to improve the quality of life and to acquire a general well-being. Among the plants sold on the market in Romania there is also the passion flower.

Passiflora is the general name of plants in the Passifloraceae family, which is mainly noted for the Passiflora genus, which comprises more than 560 species (Shrestha et al., 2019).

The genus Passiflora is native to tropical areas of the South America, and many species grow in Brazil, Colombia, Peru, even in Asia, Australia and China. Passiflora is appreciated for the production of fruits that are suitable for fresh or processed consumption, for flowers of an unusual beauty, with a huge ornamental potential and not least for the presence of phytoconstituents found in various organs of the plant that can be used in alternative medicine (Faleiro et al., 2018, Bernacci et al., 2015).

From the aforementioned considerations, the need arises for the cultivation and propagation of the genus Passiflora in Romania, especially for the climate which is changing continuously making the conditions favorable for the introduction of this species as crop of flowering plants from protected areas. The propagation of Passifloraceae family is generative propagation by seeds (Meletti et al., 2007), but it can also be successfully 
propagated by cuttings, marking or grafting (Leonel and Pedrosso, 2005). Therefore, comes the need to produce vigorous plants for good adaptability and resistance to the changing climate conditions. The use of suitable substrates and the application of different treatments to increase the production efficiency are necessary to reduce the final costs and to obtain high quality planting material. However, to obtain a suitable substrate it is recommended to mix different components such as sand, soil, coconut fiber or commercial substrates (Faleiro et al., 2018).

Propagation by cuttings from Passiflora is mainly used for commercial purposes. In Brazil, high number of rooted plants of the species Passiflora edulis Sims and Passiflora alata Curtis are obtained, with the rooting rate being over $90 \%$ (Salomão et al., 2002).

The determining factors for cutting plant propagation are: humidity, temperature, substrate, hormonal balance, the type of cutting and physiological state of the mother plant (Gomes et al., 2018). Root biostimulators can have positive effects on cuttings, incerase rooting percentage and root proliferation, representing a trend for sustainable agriculture (Nardi et al., 2016).

Thus, the present research aims to evaluate the effect of rooting substrates and biostimulators on Passiflora caerulea and Passiflora quadrangularis species in order to develop an optimal vegetative propagation protocol by cuttings.

\section{Materials and methods}

The experience regarding the possibilities of vegetative propagation by cuttings for the Passiflora caerulea and Passiflora quadrangularis species was placed in the greenhouse of the Department of Ornamental Plants, belonging to the Institute of Advanced Horticultural Research of Transylvania, of the University of Agricultural Sciences and Veterinary Medicine Cluj-Napoca. From the climatic point of view, the area in which the greenhouse is located, according to the $\mathrm{W}$. Köppen system is the climatic province Df, defined by the boreal climate with cold and humid winters and the lowest temperature recorded during winter below $-30^{\circ} \mathrm{C}$ and the highest above $10^{\circ} \mathrm{C}$ (Bunescu et al., 2005).

The biological material used to carry out the experiment was represented by cuttings approximately $15 \mathrm{~cm}$ long, respectively 2-3 nodes, harvested from mature plants in the vegetative growth stage, from the middle part of the shoot. The cuttings were trimmed by removing the basal leaves and reducing the leaf surface for Passiflora quadrangularis. In case of $P$. caerulea the leaves were kept entirely.

The research regarding the vegetative propagation by cuttings was carried out as a trifactorial experiment of the type $4 \times 4 \times 2$, in a randomized block design, in three repetitions (Ardelean et al., 2007) as follows:

Factor A - rooting substrate:

- a1 - vermiculite (V);

- a2 - peat + vermiculite in 1:1 mixture $(\mathrm{P}+\mathrm{V})$;

- a3 - peat + perlite in 1: 1 mixture $(\mathrm{P}+\mathrm{P})$;

- a4 - peat + sand in 1: 1 mixture $(\mathrm{P}+\mathrm{S})$.

Factor $\mathrm{B}$ - the rooting biostimulator:

- b1 - Incit - 8 (I8);

- b2 - Radistim - 2 (R2);

- b3 - IBA 1000 ppm (IBA);

- b4 - no treatment (Nt).

Factor C - the species:

- c1 - Passiflora caerulea;

- c2 - Passiflora quadrangularis.

By combining the three experimental factors, 32 experimental variants resulted.

At 60 days from the date of planting the cuttings, observations were carried out regarding: the number of roots emerged by each plant; the length of the roots emerged by each plant; the length of the main stem emitted by each plant; the number of shoots developed by each plant and the number of leaves. After the measurements were made, the rooted plants were planted in pots containing a mixture of peat + vermiculite $(70 \%$ $+30 \%$ ) where they were kept for 90 days, after which they were planted in the field.

The experimental data obtained regarding the variability of the morphological characters of the rooted cuttings were statistically processed using the analysis of variance (ANOVA) followed by Duncan's multiple comparison test.

\section{Results and discussions}

Based on the research carried out on the two species, Passiflora caerulea and Passiflora quadrangularis, the influence of the rooting substrate and rooting biostimulator on the rooting rate of the cuttings and on morphological characters was analyzed. 


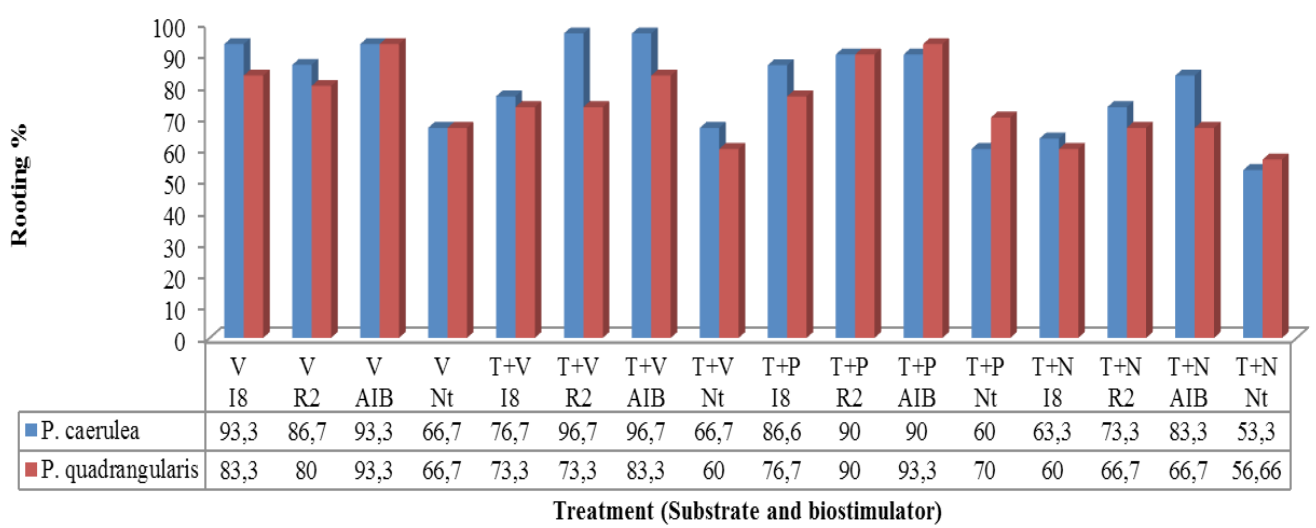

Figure 1. The rate of rooting for Passiflora cuttings depending on substrate and rooting biostimulators

Regarding the rooting rate by species (Fig. 1), it was found that Passiflora caerulea obtained an average rooting rate of $79.78 \%$, compared with Passiflora quadrangularis, which obtained an average percentage of $74.57 \%$ rooted cuttings. The cuttings of Passiflora caerulea (Fig. 2) recorded the highest rooting percentage $(96.7 \%)$ on peat + vermiculite mixing substrates following treatment with Radistim - 2 and IBA 1000 ppm. The lowest rooting rate of this species being obtained on the peat + sand substrate in the case of cuttings without biostimulator treatment. The cuttings of Passiflora quadrangularis (Fig. 3) recorded 93.3\% cuttings rooting on the vermiculite substrate and the peat + pearlite mixture associated with IBA treatment, respectively the lowest rooting rate of the species of $53.3 \%$ was obtained on the peat + sand substrate in the case of cuttings not treated with biostimulator.

According to a study that investigated the effect of some types of cuttings and the concentration of IBA $\left(0 ; 1000 \mathrm{mg} \mathrm{kg}^{-1}, 1500 \mathrm{mg}\right.$ $\mathrm{kg}^{-1}$, and $2000 \mathrm{mg} \mathrm{kg}^{-1}$ ) on rooting in Passiflora mucronata, Sobreira et al. (2016), found that the effect of IBA is dispensable for the production of plants from cuttings in this species.

\section{a. The average root length}

Root length at rooted cuttings (Tab. 1) varied between $3.73 \mathrm{~cm}\left(\mathrm{~T}_{16}\right)$ and $8.59 \mathrm{~cm}\left(\mathrm{~T}_{3}\right)$ for $P$. caerulea and between $4.77 \mathrm{~cm}\left(\mathrm{~T}_{8}\right)$ and $8.63 \mathrm{~cm}$ $\left(\mathrm{T}_{1}\right.$ ) for P. quadrangularis. Regarding the species $P$. caerulea, statistically significant differences were noted for the $\mathrm{T}_{1}, \mathrm{~T}_{7}, \mathrm{~T}_{10}, \mathrm{~T}_{12}, \mathrm{~T}_{14}, \mathrm{~T}_{15}$, and $\mathrm{T}_{16}$ variants and the P. quadrangularis cuttings obtained statistically assured differences for the $\mathrm{T}_{3}, \mathrm{~T}_{4}, \mathrm{~T}_{9}, \mathrm{~T}_{10}, \mathrm{~T}_{12}$ and $\mathrm{T}_{14}$ variants, the rest of the variants showed no statistically significant differences.

Treatment with IBA $1000 \mathrm{ppm}\left(\mathrm{T}_{3}\right.$ and $\left.\mathrm{T}_{7}\right)$ determined the absolute lengths of the upper root for the P. caerulea compared to P. quadrangularis species, the differences were statistically significant.

\section{b. The average number of roots}

The average number of roots (Tab. 1) varied between $4.16\left(\mathrm{~T}_{16}\right)$ and $11.95\left(\mathrm{~T}_{3}\right)$ for $P$. quadrangularis and between $4.84\left(\mathrm{~T}_{16}\right)$ and 10.85 $\left(\mathrm{T}_{3}\right)$ for $P$. caerulea. Regarding the $P$. caerulea species, statistically significant differences were obtained for the $\mathrm{T}_{2}, \mathrm{~T}_{3}$, and $\mathrm{T}_{11}$ treatment variants and the $P$. quadrangularis cuttings presented statistically significant differences for the $T_{2}, T_{3}$, $\mathrm{T}_{5}, \mathrm{~T}_{9}, \mathrm{~T}_{10}, \mathrm{~T}_{12}$ and $\mathrm{T}_{16}$ treatment variants, the rest of the variants showed no statistically significant differences.

\section{c. The average length of main shoot}

Regarding the length of main shoot (Tab. 1), the average recorded was between $1.35 \mathrm{~cm}\left(\mathrm{~T}_{4}\right)$ and $3.47 \mathrm{~cm}\left(\mathrm{~T}_{13}\right)$ for $P$. quadrangularis and between $1.43 \mathrm{~cm}\left(\mathrm{~T}_{12}\right)$ and $4.22 \mathrm{~cm}\left(\mathrm{~T}_{2}\right)$ for $P$. caerulea. In the case of the P. caerulea species, statistically significant differences were recorded for $\mathrm{T}_{2}, \mathrm{~T}_{3}$, $\mathrm{T}_{4}, \mathrm{~T}_{6}, \mathrm{~T}_{8}, \mathrm{~T}_{9}, \mathrm{~T}_{12}, \mathrm{~T}_{14}, \mathrm{~T}_{15}$ and $\mathrm{T}_{16}$ variants and $P$. quadrangularis cuttings obtained statistically significant differences for the $\mathrm{T}_{1}, \mathrm{~T}_{2}, \mathrm{~T}_{4}, \mathrm{~T}_{7}, \mathrm{~T}_{8}, \mathrm{~T}_{10}$ and $\mathrm{T}_{15}$ variants, the rest of the variants showed no statistically significant differences. Analyzing the combinations between factors, it was found that $P$. caerulea recorded higher average values regarding the length of the shoot, compared to 


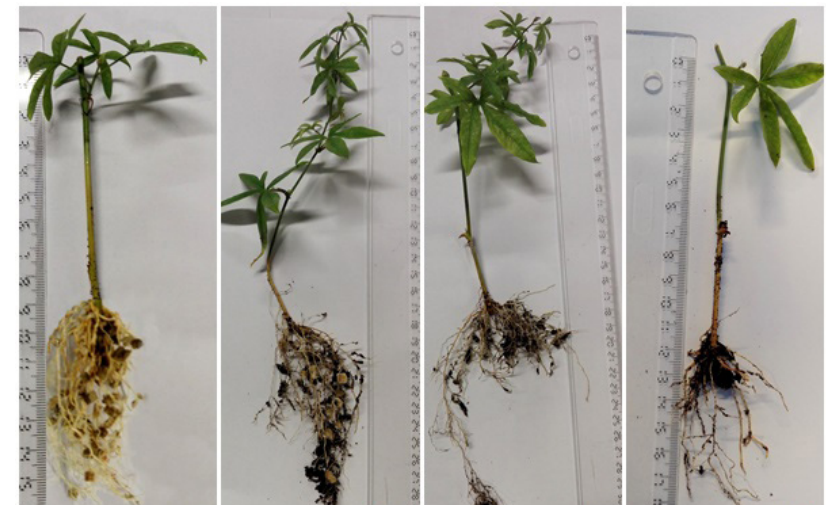

Figure 2. $P$. caerulea cuttings rooted in: a - vermiculite; $b$ - peat + vermiculite; $c$ - peat + perlite; $d$ - peat + sand

P. quadrangularis, except for $\mathrm{T}_{13}$ (3.47) where $P$. quadrangularis recorded a significantly higher value for average lenght of main shoot, the rest of variants presenting no statistically significant differences.

\section{d. The average number of shoot / cuttings}

Regarding the comparative analysis of the number of shoots emitted (Tab. 1), the average recorded varied between $0.77\left(\mathrm{~T}_{16}\right)$ and $0.94\left(\mathrm{~T}_{7}\right)$ for P. caerulea and between $1.19\left(\mathrm{~T}_{10}\right)$ and 2.10 $\left(\mathrm{T}_{2}\right)$ for $P$. quadrangularis.

In case of $P$. caerulea cuttings, the $\mathrm{T}_{7}, \mathrm{~T}_{11}, \mathrm{~T}_{13}$ and $\mathrm{T}_{16}$ treatment variants, registered statistically significant differences, the rest of the variants had no statistically significant differences. As for $P$. quadrangularis cuttings, the $\mathrm{T}_{2}, \mathrm{~T}_{3}, \mathrm{~T}_{6}, \mathrm{~T}_{7}, \mathrm{~T}_{10}, \mathrm{~T}_{12}$ and $\mathrm{T}_{13}$ treatment variants obtained statistically significant differences, the rest of the variants showed no statistically significant differences.

\section{e. The average number of leaves}

Regarding the number of leaves (Tab. 1), the average recorded was between $1.46\left(\mathrm{~T}_{5}\right)$ and 3.55 $\left(\mathrm{T}_{14}\right)$ for P. quadrangularis and between $2.00\left(\mathrm{~T}_{13}\right)$ and $4.09\left(\mathrm{~T}_{10}\right)$ for $P$. caerulea.

Analyzing the combinations between factors, it was found that $P$. caerulea recorded higher average values regarding the number of leaves, compared to $P$. quadrangularis, except for $\mathrm{T}_{13}$ (3.41) and $\mathrm{T}_{15}$ (3.37) where $P$. quadrangularis recorded a statistically significant higher number of leaves. In the case of $P$. caerulea, the treatment variants $\mathrm{T}_{2}, \mathrm{~T}_{3}, \mathrm{~T}_{8}, \mathrm{~T}_{9}, \mathrm{~T}_{10}, \mathrm{~T}_{11}$ and $\mathrm{T}_{13}$ obtained statistically significant differences and $P$. quadrangularis cuttings obtained statistically significant differences for the treatment variants

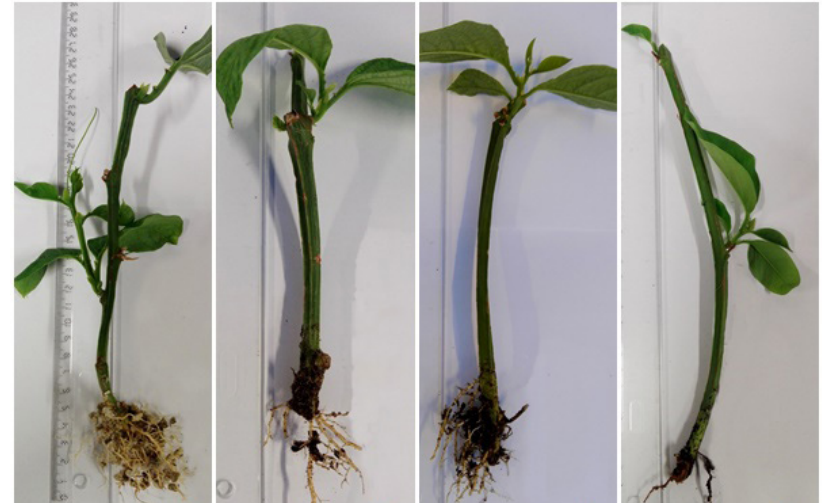

Figure 3. $P$. quadrangularis cuttings rooted in: a - vermiculite; $b$ - peat + vermiculite; $c$ - peat + perlite; $d$ - peat + sand

$\mathrm{T}_{5}, \mathrm{~T}_{7}, \mathrm{~T}_{13}$ and $\mathrm{T}_{15}$, the rest of the variants showed no statistically significant differences.

The results obtained from correlations between each of the morphological characters was presented as a correlation matrix. Regarding $P$. caerulea species (Fig. 4), using Pearson correlation coefficients, direct links evidenced by highly positive correlated values $(p<0.001)$ between the average length of the main root and the average number of roots $(r=0.94)$ respectively between the average length of the main shoot and the average number of leaves $(r=0.78)$. The average root length correlated with the average length of the main shoots $(r=0.5)$, with the average number of shoots $(r=0.56)$ and with the average number of leaves ( $r=0.5$ ) obtained a moderate correlation $(p<0.05)$. It appeared that with the growth of the root, the aerial part of the plants also grows. Also, between the average number of roots and the average number of shoots $(r=0.51)$, there was a moderate correlation.

In the case of $P$. quadrangularis species (Fig. 5), statistically significant correlation coefficient values were obtained only between the average root length and the average number of roots $(r=0.81)$, indicating variables hightly correlatied.

In contrast to the values obtained in the case of the correlation between the morphological characters in $P$. caerulea, in $P$. quadrangularis are identified negatively correlated values, no statistically significant, between the average root length and the average number of leaves $(\mathrm{r}=-0.09)$ and between the average number of roots and the average leaf number $(r=-0.17)$. No 
Table 1. Results on the interaction of substrate, rooting biostimulator and species on the morphological characters of Passiflora plants

\begin{tabular}{|c|c|c|c|c|c|c|c|c|c|c|}
\hline \multirow{3}{*}{$\begin{array}{c}\text { Variant } \\
\text { Treatment } \\
\text { (Substrate+Biostimulator) }\end{array}$} & \multicolumn{10}{|c|}{ Morphological characters } \\
\hline & \multicolumn{2}{|c|}{$\begin{array}{l}\text { The average root } \\
\text { length } \\
(\mathrm{cm})\end{array}$} & \multicolumn{2}{|c|}{$\begin{array}{c}\text { The average } \\
\text { number of roots }\end{array}$} & \multicolumn{2}{|c|}{$\begin{array}{l}\text { The average } \\
\text { length of main } \\
\text { shoot }(\mathrm{cm})\end{array}$} & \multicolumn{2}{|c|}{$\begin{array}{c}\text { The average } \\
\text { number of } \\
\text { shoots/ cuttings }\end{array}$} & \multicolumn{2}{|c|}{$\begin{array}{c}\text { The average } \\
\text { number of leaves }\end{array}$} \\
\hline & P.c. & P.q. & P.c. & P.q. & P.c. & P.q. & P.c. & P.q. & P.c. & P.q. \\
\hline $\mathrm{T}_{1}(\mathrm{~V}-\mathrm{I} 8)$ & $6.50^{\mathrm{h}-\mathrm{k}}$ & $8.63^{n}$ & $8.96^{\mathrm{i}}$ & $10.58^{\mathrm{kl}}$ & $2.41^{\mathrm{e}-\mathrm{i}}$ & $1,93^{\mathrm{b}-\mathrm{e}}$ & $0,89^{a-c}$ & $1,26^{\text {de }}$ & $2,74^{\mathrm{g}-\mathrm{i}}$ & $2,30^{d-g}$ \\
\hline $\mathrm{T}_{2}(\mathrm{~V}-\mathrm{R} 2)$ & $7.14^{\mathrm{j}-1}$ & $7.67^{\mathrm{lm}}$ & $9.42^{\mathrm{ij}}$ & $9.86^{\mathrm{jk}}$ & $4.22^{n}$ & $3,44^{\operatorname{lm}}$ & $0,88^{a-c}$ & $2,10^{\mathrm{k}}$ & $3,81^{\text {no }}$ & $2,71^{\mathrm{g}-\mathrm{i}}$ \\
\hline $\mathrm{T}_{3}(\mathrm{~V}-\mathrm{AIB})$ & $8.59^{n}$ & $8.46^{\mathrm{mn}}$ & $10.85^{1}$ & $11.95^{\mathrm{m}}$ & $2.92^{\mathrm{i}-1}$ & $2,58^{\mathrm{f}-\mathrm{i}}$ & $0,91^{\mathrm{a}-\mathrm{c}}$ & $1,60^{i}$ & $2,92^{h-j}$ & $1,89^{a-d}$ \\
\hline $\mathrm{T}_{4}(\mathrm{~V}-\mathrm{Nt})$ & $5.77^{\mathrm{e}-\mathrm{h}}$ & $7.55^{1}$ & $7.5^{\mathrm{h}}$ & $7.87^{\mathrm{h}}$ & $2.16^{\mathrm{c}-\mathrm{h}}$ & $1,35^{\mathrm{a}}$ & $0,82^{a-c}$ & $1,34^{\text {ef }}$ & $2,68^{g-i}$ & $1,62^{a b}$ \\
\hline $\mathrm{T}_{5}(\mathrm{~T}+\mathrm{V}-\mathrm{I} 8)$ & $5.61^{d-h}$ & $5.32^{\mathrm{c}-\mathrm{f}}$ & $7.55^{\mathrm{h}}$ & $5.06^{\mathrm{bc}}$ & $2.71^{\mathrm{h}-\mathrm{j}}$ & $1,69^{a-c}$ & $0,87^{a-c}$ & $1,29 \mathrm{de}$ & $2,31^{d-g}$ & $1,46^{\mathrm{a}}$ \\
\hline $\mathrm{T}_{6}(\mathrm{~T}+\mathrm{V}-\mathrm{R} 2)$ & $7.13^{j-1}$ & $5.63^{d-h}$ & $8.74^{\mathrm{i}}$ & $4.71^{\mathrm{a}-\mathrm{c}}$ & $2.54^{\mathrm{f}-\mathrm{i}}$ & $1,76^{a-c}$ & $0,83^{a-c}$ & $1,47^{\mathrm{f}-\mathrm{i}}$ & $2,54^{\mathrm{f}-\mathrm{i}}$ & $1,72^{a-c}$ \\
\hline $\mathrm{T}_{7}(\mathrm{~T}+\mathrm{V}-\mathrm{AIB})$ & $6.87^{\mathrm{i}-1}$ & $5.80^{\mathrm{e}-\mathrm{h}}$ & $10.22^{\mathrm{kI}}$ & $6.62^{\mathrm{fg}}$ & $3.68^{\mathrm{m}}$ & $2,13^{c-g}$ & $0,94^{c}$ & $1,51^{\mathrm{hi}}$ & $3,39^{k-n}$ & $2,94^{i-k}$ \\
\hline $\mathrm{T}_{8}(\mathrm{~T}+\mathrm{V}-\mathrm{Nt})$ & $6.39^{g-k}$ & $4.77^{b-d}$ & $6.06^{\text {ef }}$ & $5.18^{b-d}$ & $2.68^{g-j}$ & $1,85^{a-d}$ & $0,81^{a-c}$ & $1,34^{\text {ef }}$ & $2,45^{\mathrm{e}-\mathrm{h}}$ & $1,53^{a b}$ \\
\hline $\mathrm{T}_{9}(\mathrm{~T}+\mathrm{P}-\mathrm{I} 8)$ & $4.79^{b-d}$ & $5.69^{d-h}$ & $7.80^{h}$ & $5.49^{c-e}$ & $3.15^{j-m}$ & $1,42^{a b}$ & $0,84^{a-c}$ & $1,93^{j}$ & $3,25^{j-m}$ & $2,18^{\mathrm{c}-\mathrm{f}}$ \\
\hline $\mathrm{T}_{10}(\mathrm{~T}+\mathrm{P}-\mathrm{R} 2)$ & $7.26^{\mathrm{kl}}$ & $6.26^{f-j}$ & $6.41^{\mathrm{fg}}$ & $5.87^{d-f}$ & $3.38^{\mathrm{k}-\mathrm{m}}$ & $2,37^{\mathrm{d}-\mathrm{i}}$ & $0,82^{a-c}$ & $1,19^{\mathrm{d}}$ & $4,09^{\circ}$ & $2,33^{d-g}$ \\
\hline $\mathrm{T}_{11}(\mathrm{~T}+\mathrm{P}-\mathrm{AIB})$ & $5.87^{\mathrm{e}-\mathrm{h}}$ & $7.61^{\mathrm{Im}}$ & $7.08^{\mathrm{gh}}$ & $5.16^{b-d}$ & $2.43^{\mathrm{e}-\mathrm{i}}$ & $1,71^{a-c}$ & $0,92^{b c}$ & $1,5^{\mathrm{g}-\mathrm{i}}$ & $2,99^{\mathrm{i}-1}$ & $1,82^{a-c}$ \\
\hline $\mathrm{T}_{12}(\mathrm{~T}+\mathrm{P}-\mathrm{Nt})$ & $4.27^{\mathrm{ab}}$ & $5.43^{c-g}$ & $5.15^{b-d}$ & $4.53^{\mathrm{ab}}$ & $1.43^{\mathrm{ab}}$ & $1,50^{a b}$ & $0,89^{a-c}$ & $1,37^{\mathrm{e}-\mathrm{g}}$ & $2,61^{\mathrm{f}-\mathrm{i}}$ & $1,58^{a b}$ \\
\hline $\mathrm{T}_{13}(\mathrm{~T}+\mathrm{N}-\mathrm{I} 8)$ & $4.76^{b-d}$ & $5.78^{\mathrm{e}-\mathrm{h}}$ & $6.24^{\text {ef }}$ & $4.74^{\mathrm{a}-\mathrm{c}}$ & $2.59^{\mathrm{f}-\mathrm{i}}$ & $3,47^{m}$ & $0,78^{\mathrm{ab}}$ & $1,40^{\mathrm{e}-\mathrm{h}}$ & $2,00^{b-e}$ & $3,41^{1-n}$ \\
\hline $\mathrm{T}_{14}(\mathrm{~T}+\mathrm{N}-\mathrm{R} 2)$ & $4.53^{\mathrm{a}-\mathrm{c}}$ & $5.48^{\mathrm{d}-\mathrm{g}}$ & $5.27^{b-d}$ & $4.75^{a-c}$ & $3.3^{\mathrm{k}-\mathrm{m}}$ & $1,75^{a-c}$ & $0,88^{a-c}$ & $1,49^{g-i}$ & $3,48^{\mathrm{mn}}$ & $3,55^{\mathrm{mn}}$ \\
\hline $\mathrm{T}_{15}(\mathrm{~T}+\mathrm{N}-\mathrm{AIB})$ & $5.27^{\mathrm{c}-\mathrm{e}}$ & $6.08^{\mathrm{e}-\mathrm{i}}$ & $6.51^{\mathrm{fg}}$ & $4.71^{\mathrm{a}-\mathrm{c}}$ & $2.85^{\mathrm{i}-\mathrm{k}}$ & $2,12^{\mathrm{c}-\mathrm{f}}$ & $0,87^{a-c}$ & $1,81^{j}$ & $2,78^{g-i}$ & $3,37^{j-n}$ \\
\hline $\mathrm{T}_{16}(\mathrm{~T}+\mathrm{N}-\mathrm{Nt})$ & $3.73^{\mathrm{a}}$ & $6.07^{\mathrm{e}-\mathrm{i}}$ & $4.84^{\mathrm{a}-\mathrm{c}}$ & $4.16^{\mathrm{a}}$ & $2.65^{f-j}$ & $1,72^{\mathrm{a}-\mathrm{c}}$ & $0,77^{\mathrm{a}}$ & $1,29^{\mathrm{e}}$ & $2,16^{\mathrm{c}-\mathrm{f}}$ & $1,92^{\mathrm{a}-\mathrm{d}}$ \\
\hline DS 5\% & 0.82 & 0.99 & 0.71 & 0.86 & 0.48 & 0.58 & 0.13 & 0.15 & 0.42 & 0.50 \\
\hline
\end{tabular}

Note: The difference between any two values followed by at least one common letter is insignificant.

Legend: V - I8 = Vermiculite + Incit - 8; V - R2 = Vermiculite + Radistim - 2; V - IBA = Vermiculite + IBA 1000 ppm; V - Nt = Vermiculite - without treatment;

$\mathrm{P}+\mathrm{V}-\mathrm{I} 8=$ Peat + vermiculite - Incit $-8 ; \mathrm{P}+\mathrm{V}-\mathrm{R} 2=$ Peat + vermiculite - Radistim $-2 ; \mathrm{P}+\mathrm{V}-\mathrm{IBA}=\mathrm{Peat}+$ vermiculite $-\mathrm{IBA} 1000$ ppm; P+V $-\mathrm{Nt}=$ Peat + vermiculite - without treatment; P+P $-\mathrm{I} 8=$ Peat + perlite - Incit $-8 ; \mathrm{P}+\mathrm{P}-\mathrm{R} 2=$ Peat + perlite $-\mathrm{Radistim}-2 ; \mathrm{P}+\mathrm{P}-\mathrm{IBA}=\mathrm{Peat}+$ perlite $-\mathrm{IBA}$ 1000 ppm; P+P - Nt = Peat + perlite - without treatment; P+S - I8 = Peat + sand - Incit $-8 ; P+S-R 2=P e a t+$ sand - Radistim $-2 ; P+S-I B A=P e a t$ + sand - IBA 1000 ppm; P+S - Nt = Peat + sand - without treatment.

statistically significant correlations between the morphological characters indicated the lack of influence between the analyzed variables.

In order to determine the influence of some substances on the possibilities of rooting and growing the cuttings of passion fruit, Parse et al. (2018), applied three different treatments using IBA, ANA, salicylic acid, ethanol and control. The results of the study showed that there were significant differences between the $\mathrm{T}_{1}$ treatment (IBA $500 \mathrm{ppm}$ ) and the $\mathrm{T}_{2}$ treatment (IBA $750 \mathrm{ppm}$ ) regarding the root length, diameter and weight. However, $\mathrm{T}_{3}$ treatment (IBA $1000 \mathrm{ppm}$ ) was the most effective results. Jin et al. (2010) studied the influence of some types of rooting substrates and the type of cutting on rooting for Passiflora caerulea. The results obtained from this experiment showed that peat and vermiculite substrates were most effective, and in the perlite the rooting was deficient.

\section{Conclusion}

Regarding the rooting rate, the highest percentage of rooting for Passiflora species was obtained in cuttings treated with IBA $1000 \mathrm{ppm}$. The lowest percentage of rooting was obtained in cuttings with no treatment with rooting biostimulator in the peat + sand mixed substrate (1: 1).

Regarding the influence of the rooting substrates, vermiculite showed statistically higher values, compared to other substrates for the root length and their number. Regarding the average length of the main shoot, the average number of shoots/cuttings and the number of leaves, it was found that the rooting substrates did not have a particular influence.

From the interaction of the biostimulator with the rooting substrate, resulted that the untreated cuttings with the biostimulator $\left(\mathrm{T}_{2}, \mathrm{~T}_{4}, \mathrm{~T}_{6}\right.$ and $\left.\mathrm{T}_{8}\right)$ recorded the lowest values of the length of the shoot, from which it was concluded the importance of using the biostimulator both for facilitating 


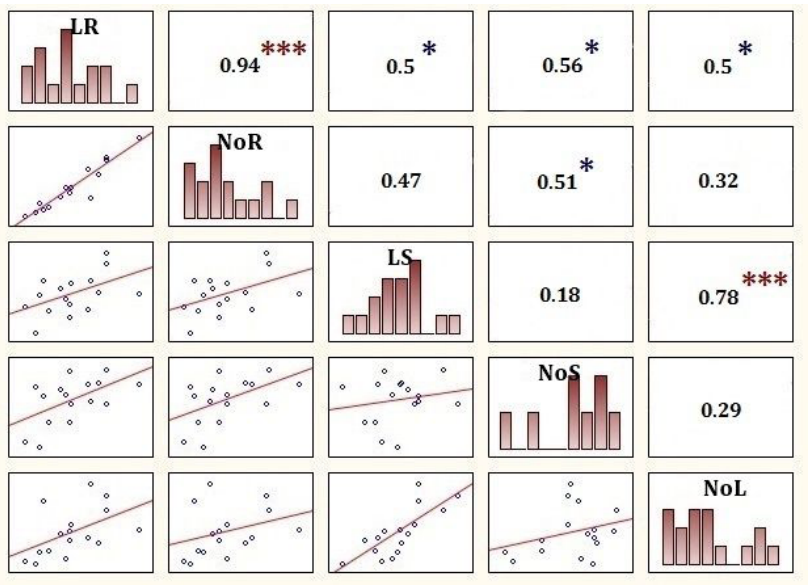

Figure 4. Correlation matrix with Pearson significance levels, variables distribution on diagonal and graphical representation of the dispersion of each pair of variables in Passsiflora caerulea

Legend: $\mathrm{RL}=$ root length; $\mathrm{NoR}=$ number of roots;

LS = length of main shoot; NoS = number of shoots / cuttings; NoL = number of leaves

the rooting, as well as for development of newly formed plants.

In the case of the P. quadrangularis species, the recorded data indicate significantly higher values for the number of developed shoots, compared to $P$. caerulea, which indicated a high capacity to shoot development for the species.

Based on the results obtained in this study, it can be concluded that the propagation of Passifloraceae by cuttings is the most efficient and it is recommended to use the vermiculite substrate, respectively the peat + vermiculite 1: 1 mixture and the treatment of the cuttings with IBA $1000 \mathrm{ppm}$.

\section{References}

1. Ardelean M, Sestras R, Cordea M (2007). Tehnică experimentală horticolă, Ed. AcademicPres, ClujNapoca.

2. Bernacci LC, Cervi AC, Milward-de-Azevedo MA, Nunes TS, Imig DC, Mezzonato AC (2015). Passifloraceae in lista de espécies da flora do Brasil. Jardim Botânico do Rio de Janeiro.

3. Bunescu V, Mihai G, Bunescu H, Man I (2005). Conditiile ecologice si solurile din Podisul Transilvaniei, Editura AcademicPres, Cluj-Napoca.

4. Faleiro FG, Vilela Junqueira NT, Góes Junghans T, Nunes de Jesus O, Miranda D, Otoni WC (2018). Advances in

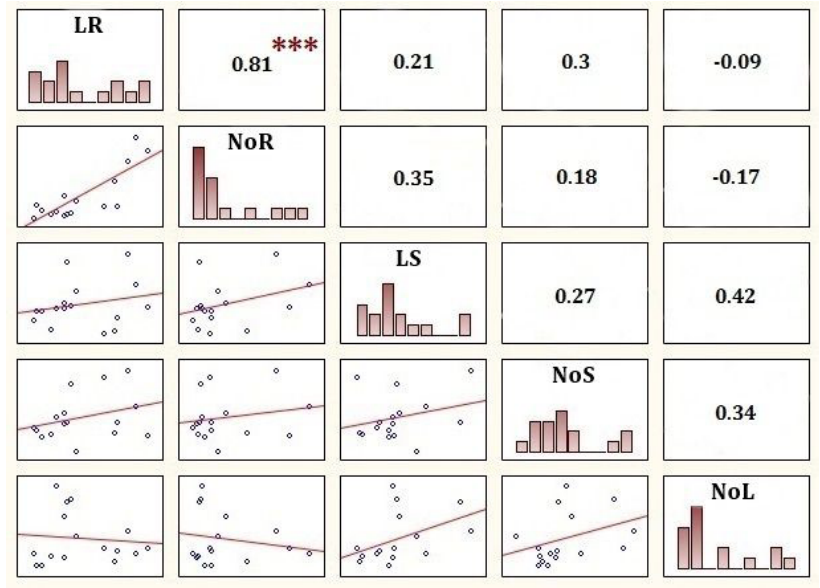

Figure 5. Correlation matrix with Pearson significance levels, variables distribution on diagonal and graphical representation of the dispersion of each pair of variables in Passsiflora quadrangularis

Legend: RL = root length; NoR = number of roots; LS = length of main shoot; NoS = number of shoots / cuttings; $\mathrm{NoL}=$ number of leaves

passion fruit (Passiflora spp.) propagation. Revista Brasileira de Fruticultura, Jaboticabal, 41(2).

5. Gomes EN, Vieira LM, De Cássia Tomasi J, Tomazzoli MM, Grunennvaldt RL, De Moraes Fagundes C, Brunetti Machado RC (2018). Brown seaweed extract enhances rooting and roots growth on Passiflora actinia Hook stem cuttings. Ornamental orticulture, 24(3): 269-276.

6. Jin L, Yuan J, Lv W, Zhou Y, (2010). Impacts of different media on the cutting rooting of Passiflora coerulea Linn. Hunan Agricultural Sciences, 18.

7. Leonel S, Pedroso CJ, (2005). Produção de mudas de maracujádoce com uso de biorregulador. Revista Brasileira de Fruticultura, Jaboticabal, 27(1): 107-109.

8. Meletti LMM, Barbosa W, Veiga RFA, Pior R (2007). Crioconservação de sementes de seis acessos de maracujazeiro. Revista Scientia Agrária Paranaensis, Marechal Candido Rondon 6: 3-20.

9. Nardi S, Pizzeghello D, Schiavon M, Ertani A, (2016). Plant biostimulants: physiological responses induced by protein hydrolyzed-based products and humic substances in plant metabolism. Scientia Agricola, 73(1) 18-23.

10. Parse RN, Mane SB, Nag UM, (2018). Effect of different chemicals on root growth success of cuttings in passion fruit. International Journal of Current Microbiology and Applied Sciences, 7 (9): 3139-3144.

11. Salomão LCC, Pereira WE, Duarte RCC, Siqueira DLD (2002). Propagação por estaquia dos maracujazeiros doce (Passiflora alata Dryand.) e amarelo (P.edulis 
f. flavicarpa Deg.). Revista Brasileira deFruticultura, Jaboticabal, 24(1): 163-167.

12. Shrestha B, Weng M-L, Theriot E C, Gilbert LE, Ruhlman TA, Krosnick SE, Jansen RK (2019). Highly accelerated rates of genomic rearrangements and nucleotide substitutions in plastid genomes of Passiflora subgenus
Decaloba, Molecular Phylogenetics and Evolution, 138: 53-64.

13. Sobreira RA, Costa PR, Chagas K, Mayrinck LG, Dutra Giles JA, Schmildt ER (2016). Different propagules and auxin concentration on rooting of passionflower sandbank. Revista Ceres, Viçosa, 63(5): 691-697. 